\title{
A EDUCAÇÃO NA CONCORDATA BRASIL-VATICANO
}

\author{
Luiz AnTÔNIO CunHA
}

\begin{abstract}
RESUMO: Este texto analisa três artigos da concordata firmada pelo governo brasileiro com o Vaticano, em novembro de 2008, concernentes à educação. Com base no texto do acordo e de notícias publicados na imprensa, o texto focaliza, especialmente, a questão do ensino religioso nas escolas públicas, situada no contexto definido pela ambigüidade do Estado brasileiro, entre o confessionalismo e laicidade.
\end{abstract}

Palavras-chave: Política educacional. Estado laico. Confessionalismo. Laicidade.

\section{EdUCATION IN BRAZIL-VaTiCAN CONCORDATA}

ABSTRACT: This paper analyses three articles from the November 2008 concordata between the Brazilian government and the Holy See, relating to education. Based on its text and on press reports, the text especially focuses the issue of religious education in public schools within the context defined by the ambiguity of the Brazilian State, between confessionalism and secularism.

Key words: Educational policy. Secular State. Confessionalism. Secularity

Doutor em Educação e professor titular do Núcleo de Estudos em Políticas Públicas de Direitos Humanos, da Universidade Federal do Rio de Janeiro (UfRJ). Home page: www.luizantonio.cunha.nom.br 
$\mathbb{E}$ m 13 de novembro de 2008, a imprensa brasileira noticiou a chegada do presidente Lula em Roma, visando entendimentos políticos com o presidente italiano Ítalo Berlusconi, com quem viajaria a Washington para a reunião do G-20. Noticiou, também, em segundo plano, a visita do presidente brasileiro ao Papa Bento XVI, no Vaticano, acompanhado de sua esposa e quatro ministros, ocasião em que foi firmada uma concordata entre os dois Estados.

Curiosa inversão! As agências internacionais destacaram a concordata, deixando em segundo plano o encontro de Lula com Berlusconi, primeiro-ministro italiano que não goza de prestígio algum no cenário internacional, tratado pela imprensa como um bufăo.

Esse encontro serviu de álibi para a viagem do presidente Lula a Roma, de modo a não deixar em evidência, para os brasileiros, a concordata com o Vaticano. A imprensa estrangeira, todavia, não caiu no engodo diplomático.

Apesar da diversidade de posições da grande imprensa nacional, a concordata foi apresentada como algo inócuo, que apenas consolida a legislação brasileira concernente à Igreja Católica. Que ficassem tranqüilos os católicos, os crentes das demais religiōes, assim como os não-crentes, pois nada mudaria. Declarações de diplomatas do Itamaraty e de cardeais repetiam afinadas essa mensagem. ${ }^{1}$ Como se o presidente Lula e o Papa não tivessem coisas mais importantes a fazer do que patrocinar tratados inócuos...

O texto da concordata trata de várias questôes de interesse para a Igreja Católica, particularmente sobre o ensino religioso nas escolas públicas, as escolas católicas, os seminários e o reconhecimento de diplomas. O foco deste artigo incide sobre essas questōes, que serão situadas no contexto político em que foram formuladas.

\section{Antecedentes}

Concordata é um termo próprio do universo simbólico da Igreja Católica. Ela é um tratado ou acordo firmado entre os governos de dois Estados, o Vaticano e um outro. Se a concordata com a Itália, em 1929, não foi a primeira, ela veio a ser a matriz das que a Igreja 
Católica veio a estabelecer com outros governos, com esse nome ou chamada de tratado, acordo ou pacto.

Naquele ano, o Papa Pio XI e o Duce Benito Mussolini firmaram uma concordata (Pacto de Latrão), pela qual o Estado italiano reconheceu certas propriedades eclesiásticas, que vieram a formar o Estado do Vaticano, introduziu o catecismo católico no currículo das escolas públicas e símbolos religiosos católicos nas escolas e outros estabelecimentos públicos, além de privilégios econômicos e políticos. A Igreja Católica, por sua vez, reconheceu o Estado italiano (que se constituiu a partir da unificação política, em 1870, pela incorporação dos Estados pontifícios). Mesmo depois da queda do fascismo, o Estado italiano vem renovando a concordata.

A Igreja Católica é a única sociedade religiosa que tem um Estado para representá-la, o Vaticano ou a Santa Sé. É imprecisa a distinção entre essas duas figuras políticas, de modo que optei pela que segue.

O Vaticano é uma monarquia eletiva, cujo chefe de Estado e de governo é o Papa, que concentra em sua pessoa os poderes legislativo, executivo e judiciário. Ele é eleito por um órgão colegiado de cardeais de todo o mundo, após a morte do antecessor, para um mandato vitalício. O Vaticano foi aceito como membro da Organização das Nações Unidas, mas não exerce o direito de voto, mantendo-se como observador. Há uma ambigüidade entre o Vaticano, instituição política, e a Santa Sé, instituição religiosa, que exerce a direção mundial da Igreja Católica. ${ }^{2}$

O Concílio Vaticano II (1962/65), convocado pelo Papa João XXIII, levou ao abandono da política de concordatas, por causa da "orientação preferencial pelos pobres". Contudo, a inflexão conservadora do pontificado de João Paulo II repôs aquele tipo de ação política no primeiro plano.

Em 23/10/1989, o governo brasileiro e o Vaticano firmaram uma concordata específica, visando a assistência religiosa às Forças Armadas, atividade que já existia havia décadas. ${ }^{3}$ A direção dessa assistência é exercida por um ordinário militar, com dignidade de Arcebispo, vinculado ao Estado Maior das Forças Armadas. A assistência, propriamente dita, é realizada nos quartéis, bases e navios por capelães militares remunerados pelo Estado brasileiro, conforme o posto como oficial da ativa. 
A concordata genérica entre o Brasil e o Vaticano entrou na pauta da imprensa brasileira no início de 2007, alguns meses antes da visita do Papa Bento XVI a São Paulo, quando se noticiou que o governo brasileiro analisava um texto proposto pela Igreja Católica. Três deputados interpelaram os ministérios das Relaçôes Exteriores e da Educação para que confirmassem essa notícia e se manifestassem sobre os termos de tal acordo. ${ }^{4}$ As resposta foram evasivas.

Algumas matérias foram publicadas em jornais, com protestos contra a concordata. Havia duas questões sensíveis em pauta: a descriminalização do aborto e a pesquisa científica com células-tronco embrionárias. Encontrava-se no Supremo Tribunal Federal uma Ação Direta de Inconstitucionalidade impetrada pelo Procurador-Geral da República, Cláudio Fonteles, contra a Lei n. 11.105/05, a chamada Lei da Bio-Segurança. ${ }^{5}$ Os defensores da descriminalização do aborto e da pesquisa científica sem a tutela religiosa temiam que uma concordata viesse a interferir nessa já complicada equação.

As matérias publicadas nos jornais apontavam para direçôes diversas, indicando a existência de divisões do governo brasileiro e até mesmo do Presidente Lula.

Uma dessas posições pôde ser percebida logo no desembarque do Papa em São Paulo, em maio de 2007. Lula beijaria a mão (ou o anel) do Papa, como fez o ex-presidente José Sarney? Ou apertaria sua mão, como o ateu ex-presidente Fernando Henrique Cardoso? Pois o Presidente Lula não beijou a mão de Bento XVI, como uns esperavam e outros temiam, mas apertou-a. Aliás, é o que prescreve o cerimonial no encontro de dois chefes de Estado, o cumprimento formal, independentemente de Lula ser católico e Bento XVI ser o dirigente máximo da Igreja Católica. A atitude do Presidente foi a de chefe de Estado, eleito por católicos e adeptos de todas as religiões, assim como por não-religiosos.

Mais do que o gesto simbólico do cumprimento, Lula teria dito ao pontífice que "o Brasil vai preservar e consolidar o Estado laico". ${ }^{6} \mathrm{Se}$ de fato disse isso, terá sido a primeira vez que um presidente brasileiro proferiu tal declaração, desde os fundadores da República - e logo a um pontífice!

$\mathrm{Na}$ véspera de seu encontro pessoal com o Papa, no Palácio dos Bandeirantes, Lula declarou à imprensa ser pessoalmente contra a interrupção da gravidez, mas "como chefe de Estado, tenho que tratar o tema 
como questão de saúde pública”. Ou seja, posição totalmente contrária à do Vaticano, que pretende que o chefe de Estado faça valer sua posição pessoal por sobre sua função pública, e que o aborto é exclusivamente questão de moral individual, posta sob a tutela religiosa.

Ao fim de alguns dias, o Presidente ficou tão positivamente impressionado com Bento XVI que desejou fazer-lhe "uma concessão política moderada". ${ }^{7}$ Não sendo possível assinar o texto proposto pelo Vaticano, por causa da divisão do governo (e de si mesmo), assim como das previsíveis reaçôes de setores religiosos e de laicos, haveria tempo para negociar outro texto, a ser firmado até o fim de seu mandato, em 2010.

Não só o Presidente Lula, mas todo o governo brasileiro estava atravessado por essa divisão: de um lado, os partidários de uma democracia laica, na qual a liberdade religiosa fosse contrapartida da efetiva separação dos campos político e religioso; de outro, os defensores de uma laicidade adjetivada de "verdadeira", "positiva" ou "autêntica", 8 que significava o privilegiamento de uma religião sobre as demais, a "religião da maioria dos brasileiros", naturalmente merecedora dos favores do Estado.

Feitas as contas, prevaleceu o lado confessional, católico e vaticanista. O papel decisivo da antiga amizade de Lula com o cardeal Cláudio Hummes, nessa opção, não é uma hipótese desprovida de fundamento. Ele havia sido bispo de São Bernardo, quando Lula presidia o Sindicato de Metalúrgicos. Nessa ocasiāo, o prelado prestou importante apoio aos movimentos grevistas dos trabalhadores e protegeu várias lideranças perseguidas pela polícia política. Já cardeal, ele foi nomeado por Bento XVI para o cargo de Prefeito da Congregação para o Clero, um posto estratégico na política de "realinhamento doutrinário" da Igreja Católica. Não é descabido pensar que o articulador da concordata, do lado do Vaticano, tenha sido, justamente, o cardeal Hummes, antigo amigo de Lula e de dona Marisa, alguém que dificilmente teria um pedido negado pelo Presidente.

Religião no currículo: questão fechada

No que diz respeito ao Brasil, a Igreja Católica é a única instituição que sempre fechou questão em torno do ensino religioso nas escolas públicas. As Igrejas Evangélicas tradicionalmente foram contra 
sua inclusão obrigatória nos currículos do sistema público de ensino. As Igrejas Pentecostais, mais recentes, não fecharam questão sobre isso - umas são manifestamente contra, outras se dividem. ${ }^{9}$

A razão de tamanho empenho da Igreja Católica tem bases doutrinárias e históricas. Como ela não aceitou ser separada dos Estados, situação a que foi compelida, os documentos pontifícios determinaram que as famílias católicas pusessem seus filhos em escolas confessionais católicas, de modo a assegurar a reprodução religiosa, de uma geração a outra, garantida a ortodoxia doutrinária. O ensino público deveria se manter em papel subsidiário, apenas para os nãocatólicos, e o Estado deveria fornecer apoio financeiro para as famílias pobres manterem seus filhos nas escolas religiosas. ${ }^{10}$ Mesmo assim, as escolas públicas deveriam oferecer, obrigatoriamente, a disciplina Ensino Religioso para as crianças e os jovens que, por alguma razão, não fossem matriculados nas escolas confessionais, assim como para dar uma oportunidade para quem não tivesse recebido em casa a orientação adequada, isto é, católica.

$\mathrm{Na}$ história educacional do Brasil, foi difícil a retirada da educação escolar do controle direto da Igreja Católica. Ainda no período imperial, quando ela era parte integrante do Estado, foi só em 1879 que os alunos não-católicos foram dispensados de frequentar as aulas de Doutrina Cristã nas escolas públicas e os professores não-clérigos, por sua vez, foram dispensados de prestar juramento de fé católica.

No entanto, o conteúdo do ensino continuou imerso no catolicismo, o que constrangia uma população que se diversificava rapidamente, com o crescimento do número de evangélicos, espíritas, maçons, positivistas, agnósticos etc. A instituição do regime republicano, em 1889, abriu caminho para que a laicidade fosse inscrita na Carta Magna. Aliás, a única vez em que a laicidade aparece explícita numa Constituição brasileira foi em artigo sobre a educação: "será leigo (isto é, laico) o ensino nas escolas oficiais". ${ }^{11}$ Essa situação mudou radicalmente com a Revolução de 1930, em cuja correlação de forças estava presente um componente fascista, que mostrou sua efetividade no campo educacional. ${ }^{12}$ Foi por proposta do ministro da Educação que um decreto de Vargas incorporou a reivindicação dos dirigentes da Igreja Católica para a volta do ensino religioso ao currículo das escolas públicas, o que se materializou no Decreto n. 19.941/31. A Constituição 
de 1934 incorporou essa demanda, no que foi seguida por todas as demais, inclusive a de 1988. Restou um ponto que nenhuma Constituição definiu: quem deve pagar a conta do ensino religioso nas escolas públicas? A primeira LDB, de 1961, assim como a segunda, de 1996, estabeleceram que o ônus dessa disciplina (basicamente o pagamento dos docentes) não seria do poder público. Todavia, ambas foram alteradas, por demanda da Igreja Católica, diretamente aos governantes.

Com base no capital político acumulado durante o processo constituinte, a Conferência Nacional dos Bispos do Brasil (CNBB) aperfeiçoou sua atuação hegemônica, mediante a criação do Fórum Permanente do Ensino Religioso (FONAPER), entidade civil que congrega sócios individuais e institucionais. Essa entidade atua em todo o país e desenvolve uma dupla atividade. No interior do campo religioso, ela exerce a posição diretiva da Igreja Católica sobre as demais confissōes religiosas, especialmente as do tronco cristão; fora desse campo, ela exerce influência sobre os campos político e educacional. Essa influência tem o sentido da defesa da efetivação do ensino religioso nas escolas públicas e da inclusão, na legislação de cada sistema, de um conteúdo interconfessional, com professores credenciados pelas entidades religiosas, inseridos no corpo docente por concursos públicos e remunerados pelo Estado.

A atuação do FONAPER tem se mostrado eficaz diante da maior diversidade e do menor controle burocrático das Igrejas Evangélicas. Assim é que, uma após outra, as unidades da Federação vêm aprovando leis que incorporam, mais ou menos completamente, a plataforma daquela entidade.

\section{A educação na concordata}

Antes de entrar, diretamente, na presença de temas educacionais na concordata, cabe um comentário sobre o texto firmado. Como é comum em textos desse tipo, ele se inicia por considerações de ordem geral. A primeira delas refere-se às responsabilidades de ambas as partes "a serviço da sociedade e do bem integral da pessoa humana". Ora, a responsabilidade do Estado diante da sociedade é algo inquestionável, na letra, embora bem questionável na prática. Mas, o que dizer de sua responsabilidade diante do bem integral da pessoa humana? Não é difícil 
chegar à conclusão de que se trata de uma concepção religiosa e não há dúvida de que o Estado brasileiro não tem, nem pode ter posição sobre isso. A Constituição brasileira não tem nenhum dispositivo que autoriza o Presidente da República a firmar um acordo internacional com esse ponto de partida. Não se trata de uma expressão solta, eventualmente inserida para efeito decorativo nas considerações iniciais. Vamos reencontrá-la no artigo que trata do ensino religioso, como veremos adiante.

Os 20 artigos da concordata tratam de diferentes assuntos, dentre os quais os seguintes: organização e personalidade jurídica das instituiçôes eclesiásticas; imunidades, isenções e benefícios fiscais; patrimônio cultural; casamento; regime trabalhista de religiosos.

Três artigos tratam de temas especificamente educacionais: reconhecimento de títulos acadêmicos, instituições de ensino católicas e ensino religioso nas escolas públicas. Os dois primeiros temas são de fato inócuos, como qualificou, todo o texto, a diretora do Departamento da Europa do Itamaraty, no dia em que a concordata foi assinada, mas o terceiro artigo acarreta conseqüências deletérias para a educação brasileira. Os três artigos são transcritos abaixo, literalmente, seguidos dos comentários concernentes a cada um.

Artigo $9^{\circ}-\mathrm{O}$ reconhecimento recíproco de títulos e qualificações em nível de Graduação e Pós-Graduação estará sujeito, respectivamente, às exigências dos ordenamentos jurídicos brasileiro e da Santa Sé.

O Vaticano mantém instituições que conferem graus acadêmicos, das quais a mais famosa é a Universidade Gregoriana. Seus títulos têm sido reconhecidos no Brasil de acordo com os trâmites a que estão sujeitos os conferidos por todas as universidades, inclusive as mais importantes do mundo, como as de Harvard, de Oxford, de Paris ou de Frankfurt. Não há ameaça alguma de rejeição dos títulos da Universidade Gregoriana, ou congênere pontifícia. A revalidação dos diplomas depende apenas de parecer de uma universidade brasileira que tenha curso similar. Até mesmo as universidades privadas, inclusive as pontifícias, podem fornecer essa revalidação. Não se conhece intenção de rejeitar a revalidação dos diplomas das universidades pontifícias, que possa servir de pretexto para incluir esse artigo em tratado internacional. Para que tentar garantir o que é líquido e certo, algo que ninguém discute? 
Artigo 10 - A Igreja Católica, em atenção ao princípio de cooperação com o Estado, continuará a colocar suas instituiçōes de ensino, em todos os níveis, a serviço da sociedade, em conformidade com seus fins e com as exigências do ordenamento jurídico brasileiro.

Parágrafo $1^{\circ}$ - A República Federativa do Brasil reconhece à Igreja Católica o direito de constituir e administrar Seminários e outros Institutos eclesiásticos de formação e cultura.

Parágrafo $2^{\circ}-\mathrm{O}$ reconhecimento dos efeitos civis dos estudos, graus e títulos obtidos nos Seminários e Institutos antes mencionados é regulado pelo ordenamento jurídico brasileiro, em condição de paridade com estudos de idêntica natureza.

A vagueza da expressão "a serviço da sociedade" legitima os fins de todas as instituições educacionais da Igreja Católica, desde os colégios destinados à reprodução cultural das elites até as escolas populares das periferias urbanas. Ora, não existe partido político com representação no Congresso Nacional que defenda, manifesta ou dissimuladamente, o fim da liberdade de ensino, particularmente das escolas, faculdades ou universidades católicas. Ademais, nunca foi contestado, no Brasil, o direito da Igreja Católica constituir e administrar seminários para a formação de seus próprios quadros. Tampouco houve qualquer rejeição a que seus certificados e diplomas tenham efeito, fora do âmbito religioso, se atenderem à legislação educacional brasileira. Também aqui vale a estranheza de que esse artigo faça parte de um documento internacional. Repetimos a pergunta: para que tentar garantir o que é líquido e certo, algo que ninguém discute?

Artigo 11 - A República Federativa do Brasil, em observância ao direito de liberdade religiosa, da diversidade cultural e da pluralidade confessional do País, respeita a importância do ensino religioso em vista da formação integral da pessoa.

Parágrafo $1^{\circ}$ [aliás, parágrafo único] - O ensino religioso, católico e de outras confissões religiosas, de matrícula facultativa, constitui disciplina dos horários normais das escolas públicas de ensino fundamental, assegurado o respeito à diversidade cultural religiosa do Brasil, em conformidade com a Constituição e as outras leis vigentes, sem qualquer forma de discriminação.

Ao contrário dos outros dois, o conteúdo deste artigo remete a algo que a Igreja Católica tem a perder. Como vimos, ela sempre fechou 
questão sobre a inclusão da religião nos currículos escolares das escolas públicas, assim como na transferência dos custos para o Estado. Ao contrário dos artigos $9^{\circ}$ e 10 , contra os quais nada consta e ninguém contesta, o artigo 11 pretende manter uma disciplina contra a qual há um amplo movimento, embora inorgânico (ainda?). Trata-se da retirada da obrigatoriedade de oferta pelas escolas públicas da que é a única disciplina mencionada pela Constituição - o ensino religioso. $\mathrm{O}$ simples fato de tal obrigatoriedade constar da Carta Magna já denota a existência de uma força contra a qual esse dispositivo foi inserido - a laicidade difusa, prevalecente no âmbito do professorado e da população. Todavia, a laicidade pode se tornar densa e orgânica, animada pelos movimentos em prol dos direitos sexuais e reprodutivos, em especial, pelos movimentos feministas, inclusive católicos. ${ }^{13}$

Depois das derrotas das posiçôes laicas nas Constituintes de 1934, 1946 e 1988, o ressurgimento da luta pela supressão dessa disciplina nos currículos das escolas públicas é induzido pelos movimentos de mulheres, principalmente, assim como da reação contra as tentativas de submeter a atividade educacional à prática religiosa. Cumpre registrar que as tentativas de tutela religiosa da Igreja Católica têm sido copiadas por algumas Igrejas Evangélicas, ainda que os métodos difiram. ${ }^{14}$

Passemos ao conteúdo do artigo 11. Ele contraria, essencialmente, o artigo 33 do texto reformado da LDB, o qual determina que o conteúdo da disciplina Ensino Religioso seja estabelecido pelos sistemas de ensino (especificamente pelos respectivos conselhos de educação), depois de ouvidas entidades civis constituídas pelas diversas confissões religiosas. Assim, pode não haver "ensino religioso católico", nem de confissão específica alguma. Se esse conteúdo for de caráter histórico, sociológico ou antropológico, ou uma mescla das doutrinas religiosas conveniadas etc., dependerá da composição de tais entidades civis. A pressão ou a sedução vaticana terão sido tão fortes a ponto de o Presidente Lula ter autorizado a assinatura de um texto com tão flagrante ilegalidade? Não se trata de equívoco dos proponentes. Com efeito, o texto da concordata toma partido numa luta que divide o campo religioso no Brasil, luta na qual o Estado não pode se envolver: a disciplina Ensino Religioso deve ser confessional ou interconfessional? A mudança da LDB em 1997 tomou partido pela versão interconfessional, mas o 
estado do Rio Janeiro aprovou lei, em 2000, que instituiu a versão confessional. A decisão da Assembléia Legislativa fluminense, frequentemente atribuída à iniciativa do governador Anthony Garotinho, evangélico, foi, todavia, oriunda da arquidiocese católica.

A importância dessa luta interna ao campo religioso pode ser percebida por artigo publicado em $O$ Globo, de 14 nov. 2008 (dia seguinte ao da assinatura da concordata), pelo bispo de Petrópolis (RJ), Filippo Santoro, cotado para cardeal do Rio de Janeiro, na vaga que se anuncia será aberta proximamente. Entre os "muitos pontos de grande importância do acordo", o bispo Santoro menciona, enfaticamente, a concepção confessional do ensino religioso nas escolas públicas, em oposição a uma "religião genérica, aconfessional, indefinida, já que tal religião não existe".

A ambiguidade marca o caput do artigo 11. Uma leitura possível seria a seguinte: o Estado brasileiro respeita o ensino religioso ministrado nas escolas católicas em vista da formação integral da pessoa, conforme a concepção pedagógica da Igreja Católica. Nada contra esse respeito do Estado, que, aliás, está garantido pelo artigo $3^{\circ}$ da LDB. Com efeito, o "pluralismo de idéias e concepções pedagógicas" é um dos princípios do ensino. Assim entendido, o conteúdo do caput seria inócuo, mas não seria ilegal. Contudo, o parágrafo $1^{\circ}$, aliás, parágrafo único, não trata das escolas católicas, mas, sim, das escolas públicas, o que invalida aquela leitura. Pela lógica jurídica, o conteúdo de um parágrafo só pode ter a ver com o conteúdo do caput. Portanto, ele só pode se referir a todo o ensino, inclusive o ministrado pelas escolas públicas, as quais teriam por objetivo, como todas as outras, a formação integral da pessoa - o que ofende a legislação educacional brasileira.

Em defesa da concordata, uma argumentação matreira poderia se contrapor e sugerir que a LDB emendada diz, no artigo 33, que o ensino religioso foi reconhecido como parte integrante da formação do cidadão. No entanto, "parte integrante da formação do cidadão" não é equivalente a "formação integral da pessoa". Tornar as expressões equivalentes por causa do termo integral, que está nas duas, é de um primarismo que não pode ser endossado pelo Congresso Nacional. Como pôde o Ministério da Educação, que opinou sobre os termos da concordata, ter consentido com tal formulação? Ou não consentiu, mas perdeu? Ou será que a sedução vaticana foi irresistível? 
Aliás, as discussões sobre esse artigo devem ter sido mesmo fortes e talvez tenham durado até o último momento. Isso explicaria porque o artigo 11 tem um parágrafo primeiro, não um parágrafo único, como seria de esperar. Difícil imaginar que isso se deva a um mero erro de revisão. Um erro tão elementar não poderia ter escapado dos diplomatas do Itamaraty e do Vaticano. Como as negociações foram feitas em segredo, e só se conhecem fragmentos das versôes anteriores, é lícito supor que houvesse um artigo segundo, ainda mais agressivo do que o primeiro, no entanto suprimido no último minuto, pelo lado brasileiro.

Tudo somado, não há como aceitar que a concordata apenas repete o que diz a legislação brasileira, como declararam, em uníssono, diplomatas e prelados, brasileiros e vaticanos. No que concerne à educação, os artigos $9^{\circ}$ e 10 são, de fato, reiterativos. Contudo, esse não é o caso do artigo 11, que está em total desacordo com o conjunto da LDB e da própria Constituição, além de tomar partido nas disputas que hoje dividem o campo religioso, com o que o Estado brasileiro nada tem a ver.

Refazendo, agora, a pergunta a respeito dos artigos $9^{\circ}$ e 10: para que tentar garantir o que é líquido e certo, algo que ninguém discute? A resposta bem pode ser a seguinte: para dissimular o artigo 11, que é totalmente inconstitucional.

\section{Prospectiva}

Não é imaginável que a Igreja Católica precise de ter regulamentada sua atuação no Brasil, a ponto de necessitar de uma concordata. Se fosse na República Popular da China (RPC), por exemplo, isso seria crível. Nesse país, o governo dificulta a atuação da hierarquia eclesiástica e até mesmo os cultos, de modo que a Igreja Católica sobrevive numa faixa que beira a clandestinidade, de um lado, e da oficialidade forçada, de outro. Uma concordata com a RPC teria todo sentido, pois estabeleceria os marcos jurídicos para a atuação religiosa, explicitando os parâmetros do Estado chinês e da Igreja Católica. No entanto, no Brasil, onde ela desfruta de privilégios históricos, que interesses estão ameaçados? Por quem? Como vimos, no caso do ensino religioso nas escolas públicas, a concordata arrasta o Estado brasileiro para a posição 
de protagonista nos conflitos internos ao campo religioso, o que é flagrantemente inconstitucional.

É de se esperar que um acordo internacional bilateral defina os interesses das duas partes. Não é o caso desta concordata, que é um elenco de itens de interesse exclusivo da Igreja Católica, que não inclui um só que expresse o interesse do Estado brasileiro. Teria sido diferente se o Vaticano e a República Federativa do Brasil firmassem um acordo de cooperação na luta por interesses de ambos, como, por exemplo, a troca de informaçōes sobre o tráfico internacional de pessoas (mulheres para a prostituição e crianças para adoção clandestina). Haveria ampla base política para um acordo desse tipo, contra o qual não pesaria dúvida alguma de favorecimento religioso. Nenhum crente, de religião alguma, ou agnóstico poderia argumentar contra a pertinência de tal acordo, apenas sobre os termos, que poderiam não estar bem redigidos ou não abranger todas as facetas da questão. Nada contra sua legitimidade. Não é esse o caso da concordata firmada em novembro de 2008, cuja inconstitucionalidade é flagrante.

A iniciativa de firmar acordos internacionais é do Presidente da República, mas dependente de referendo do Congresso Nacional (Constituição de 1988, art. 84, viII). Pela letra da Constituição, o presidente não precisa pôr em discussão na sociedade, nem no Congresso, algum tratado que pretende firmar. Pela boa prática política, entretanto, temas polêmicos, com alto potencial de geração de conflitos, precisam ser submetidos ao crivo da discussão pública. Por que a concordata foi urdida em segredo, até mesmo dos congressistas que serão chamados a referendá-la? Por que dissimular até mesmo seu nome, trocando-o por acordo? ${ }^{15}$

Creio que a explicação tenha sido a criação de um fato político, não consumado, todavia de mais difícil reversão. Não seria difícil de prever a reação dos evangélicos, dos laicos, até mesmo de católicos, contra a concordata se ela fosse conhecida antes de ser assinada no Vaticano. Agora, firmada e divulgada, seu sucesso dependerá das conjunturas políticas a que o Congresso é tão suscetível. Como aconteceu no caso da proposta de um feriado nacional para Frei Galvão, canonizado pelo Papa durante sua visita ao Brasil, em 2007. O Congresso rejeitou o projeto do deputado Francisco Dornelles (PPB-RJ) e acabou por conceder-lhe um dia de homenagem no calendário simbólico, mas sem feriado nacional, nem ponto facultativo. 
Na zona cinzenta resultante da laicidade do Estado, no Brasil, as posições do Presidente Lula não devem se desprezadas, mesmo refletindo ambiguidades. Com efeito, suas reiteradas manifestações a respeito do aborto como questão de saúde pública e do caráter cínico de sua rejeição assumem grande importância, em vista da tutela religiosa sobre a moral coletiva, que, em nosso país, entranhou-se na legislação, ainda mais do que nas mentalidades.

Até agora, as reações à concordata foram poucas, mas enérgicas.

O ponto de partida foi a análise da retração da imprensa brasileira diante da assinatura do acordo, que foi tema da sessão televisiva do Observatório da Imprensa, dirigido por Alberto Dines, na TV Brasil, no dia 18/11/2008. "Entre as hipóteses de uma "barriga coletiva" e a autocensura da imprensa, Dines optou pela segunda. Os convidados foram Roseli Fischmann, Guilermino Silva da Cunha e Hugo Sarubbi Cysneiros. Os dois primeiros produziram textos, imediatamente após o programa, que serão referidos abaixo. Do terceiro, serão apresentadas idéias captadas no programa ao vivo.

Roseli Fischmann, professora da Faculdade de Educação da Universidade de São Paulo, escreveu artigo publicado na versão digital do Jornal da Ciência, da SBPC, em 10/12/2008, no qual atenta para o fato de que a concordata alça a Igreja Católica a um patamar oficialmente diferenciado das demais religiões, denominações e formas de crer, não crer e descrer, em total desacordo com os princípios elementares do Estado laico. Mais do que isso, ela chama a atenção para o fato de que, uma vez firmada a concordata, ela dificilmente poderá ser revertida. Acordos bilaterais não podem ser simplesmente desfeitos unilateralmente, eles exigem novas negociações. Caso homologada, a concordata passará a integrar o direito brasileiro, de modo que o Congresso ficará com seus atos "amarrados" pelos termos do acordo que ele próprio terá consentido. Em síntese, o Congresso deve rejeitar a concordata. ${ }^{17}$

Guilermino Silva da Cunha, pastor presidente da Catedral Presbiteriana e do Presbitério do Rio de Janeiro, enviou carta aberta ao Presidente e ao Vice-Presidente da República, aos Presidentes da Câmara dos Deputados, do Senado e do Supremo Tribunal Federal, assim como a parlamentares evangélicos de quatro diferentes denominaçóes. O pastor denunciou a concordata por trazer de volta "praticamente todos os privilégios do padroado". No que concerne ao ensino religioso 
nas escolas públicas, afirmou que o documento é inconstitucional, pois "privilegia uma denominação cristã em detrimento de outras e agride a liberdade religiosa em relação a judeus, budistas, espíritas e muçulmanos; e agride agnósticos e ateus". A carta termina com um apelo ao Congresso Nacional para que não homologue a concordata. Pediu, também, a revisão constitucional, de modo a se deixar para as famílias e suas respectivas denominaçôes e/ou confissões religiosas a educação religiosa. Para bom entendedor: a supressão da obrigatoriedade de oferta da disciplina ensino religioso, em qualquer de suas modalidades, nas escolas públicas de ensino fundamental. ${ }^{18}$

Hugo Sarubbi Cysneiros, advogado da CNBB, declarou ser muito natural a assinatura da concordata, que fez questão de chamar de tratado. Repetindo o dito pelos cardeais do Vaticano e diplomatas do Itamaraty, disse que ela (ou ele) nada mais fez do que dar um estatuto jurídico à Igreja Católica no Brasil. Ela (ou ele) foi firmada(o) com a Santa Sé por ser um Estado soberano. Se outras religiões não têm personalidade jurídica no direito internacional público, por razões históricas, políticas ou circunstanciais, então elas não podem firmar documentos com o Estado brasileiro. Simples assim. A despeito disso, o advogado afirmou que não via privilégio algum na concordata (ou no tratado).

Partindo de posição distinta, confundindo laicidade com interconfessionalidade, o FONAPER também expôs uma constrangida rejeição à concordata. Situado no cruzamento do campo religioso com o campo educacional, a entidade emitiu um "Manifesto referente ao acordo entre Brasil e Santa Sé", ${ }^{19}$ no qual a entidade expôs sua preocupação diante do artigo 11, por alinhar-se com a concepção confessional do ensino religioso nas escolas públicas, contrária à LDB e aos parâmetros curriculares nacionais dessa disciplina, elaborados pelo próprio FONAPER, que o defende interconfessional. Como a entidade tem o respaldo político da própria Igreja Católica, constituindo aparelho de hegemonia sobre as demais organizações religiosas, seu manifesto é mais um sintoma da divisão do campo religioso acirrada pela concordata.

Propondo uma ação concreta, a "Campanha Brasil para Todos" propôs uma petição contra a homologação da concordata pelo Congresso, com o seguinte conteúdo: ${ }^{20}$ 
Nós, abaixo assinados, entendemos que a concordata assinada entre o Brasil e o Vaticano no dia 13 de novembro de 2008 constitui uma violação a princípios básicos da democracia brasileira e uma afronta à Constituição do país, particularmente o art. 19, que proíbe o Estado de subvencionar ou estabelecer aliança com cultos religiosos ou igrejas. Ao invés de procurar diminuir as desigualdades que sofre o país, esse acordo as promove, criando privilégios à custa do erário e violando direitos fundamentais de milhões de cidadãos brasileiros.

Passando das reações imediatas para a tramitação da concordata no Congresso, podemos imaginar dois cenários. No primeiro, a tramitação será lenta, podendo a votação ficar para o mandato do sucessor de Lula, caso em que uma eventual rejeição não acarretaria perda de prestígio para o atual presidente. Até porque não foi Lula e Bento XVI que assinaram a concordata, mas o ministro das Relaçóes Exteriores e o secretário de Estado do Vaticano. No segundo cenário, ela será votada ainda durante o atual mandato presidencial, hipótese em que é possível prever que sejam levados para dentro do campo político (do Congresso Nacional) os conflitos que dividem o campo religioso. Em 2009, quando serão definidos os parâmetros da disputa presidencial de 2010, é imprevisível o desfecho da interiorização desses conflitos.

Em ambos os cenários, o resultado da votação no Congresso dependerá da conjuntura política imediata que terão, como co-produtores, os movimentos pela laicidade do Estado, com motivação direta nos direitos sexuais e reprodutivos, os quais se baseiam nos movimentos feministas, sua vanguarda mais ativa.

No campo educacional, objeto deste artigo, as posições laicas são majoritariamente difusas, mas podem tornar-se orgânicas por indução daqueles movimentos. Neste sentido, a manifestação das entidades que congregam educadores poderá assumir um papel pedagógico inédito, desde o Manifesto dos Pioneiros da Educação Nova, de 1932. Seria de grande alcance político se algumas dessas entidades viessem a tomar a dianteira na luta por uma reforma constitucional que suprimisse da Carta Magna a única menção a um conteúdo curricular, a obrigatoriedade de oferta da disciplina Ensino Religioso. Se isso acontecer, a ofensiva político-diplomática vaticana terá contribuído para induzir o contraponto dialético de seu desideratum maior no campo educacional.

Recebido em janeiro de 2009 e aprovado em fevereiro de 2009. 


\section{Notas}

1. A imagem grotesca ficou por conta de Maria Edileuza Fontenele Reis, diretora do Departamento da Europa do Itamaraty, que foi reproduzida em jornais brasileiros: "Não tem nenhuma malandragem, se tivesse, meu pescoço é que iria para a forca" ( $O$ Globo, 13 nov. 2008, p. 10; Folha de S. Paulo, 13 nov. 2008, p. A-10). Difícil não supor que essa imagem quisesse assinalar justamente o contrário. Figura de retórica ou lapso inconsciente?

2. Essa ambiguidade não existe no caso da Igreja Anglicana, cuja chefia é exercida pelo Rei ou pela Rainha da Inglaterra. Entre as funçōes desta, enquanto dirigente eclesiástico e as de chefe de Estado, há total distinção política.

3. Veja o texto na página do Ministério das Relações Exteriores, disponível em: <www2.mre. gov.br/dai/b_santa_03_3677.htm>

4. Esses deputados situavam-se em distintas posições do espaço político: Ivan Valente, do PSOL-DF; Fernando Gabeira, do PV-RJ; e Raul Jugmann, do PPS-PE.

5. Este foi um caso, entre numerosos outros, em que um detentor de cargo público faz dele instrumento de suas convicções pessoais. Por ser católico e afinado com a doutrina vaticana, Fonteles usou o cargo de Procurador da República para tornar-se uma espécie de procurador da Santa Sé.

6. Essa declaração de Lula foi transmitida à imprensa por Vera Machado, embaixadora do Brasil junto ao Vaticano.

7. Kennedy Alencar, "Em segredo, Lula continua a negociar acordo com o papa", Folha OnLine, 15 jul. 2007, acesso em: 17 jul. 2007.

8. A adjetivação da laicidade vem, frequentemente, para mudar-lhe a substância. É elucidativo que o bispo de Petrópolis (RJ) Filippo Santoro, e o ministro Ives Gandra, do Tribunal Superior do Trabalho, tenham publicado artigos em $O$ Globo, no dia seguinte ao da assinatura da concordata, elogiando seu texto e evocando os ensinamentos do Presidente da República Francesa, a respeito de uma "laicidade positiva". Tal expressão foi empregada por Nicolas Sarkozy, justamente por ocasião da visita de Bento XVI à França.

9. Para conhecer a posição de dirigentes e teólogos de várias religiōes, favoráveis à laicidade do Estado, veja <www.nepp-dh.ufrj.br/ole/posicionamentos6.html>.

10. Essa posição foi ostensiva no Brasil dos anos de 1950, em campanha que resultou na Lei de Diretrizes e Bases da Educação Nacional, de 1961.

11. Expressão sinônima no contexto da primeira Constituição republicana, a secularização dos cemitérios resultou de luta que vinha dos tempos imperiais.

12. O primeiro titular do recém-criado Ministério da Educação foi Francisco Campos, um intelectual orgânico do fascismo no Brasil, inclusive de sua adaptação a um regime autoritário sem a mobilização de massas que caracterizou os regimes europeus. Além de ministro da Educação, no governo provisório, Campos foi ministro da Justiça no Estado Novo, cuja Constituição outorgada foi por ele redigida.

13. Um importante exemplo é o movimento "Católicas pelo Direito de Decidir". Disponível em: <www.catolicasonline.org.br>

14. Enquanto as iniciativas católicas recaem, principalmente, sobre a disciplina Ensino Religioso nas escolas públicas, as iniciativas evangélicas incidem sobre a leitura da Bíblia nessas escolas.

Educ. Soc., Campinas, vol. 30, n. 106, p. 263-280, jan./abr. 2009

Disponível em <http://www.cedes.unicamp.br> 
15. Em Portugal, a concordata de 2004, que alterou a de Salazar, de 1940, foi chamada pelo nome próprio no texto e nas discussóes no âmbito do parlamento e da sociedade. Sua estrutura é a mesma da firmada com o Brasil.

16. Veja a matéria disponível em: <www.observatoriodaimprensa.com.br/artigos.asp? $\operatorname{cod}=511 \mathrm{IMQ} 009>$

17. Texto disponível em: <www.jornaldaciencia.org.br/Detalhe.jsp?id=60450>

18. Texto da carta disponível em: <www.catedralrio.org.br/images/stories/downloads/ oficioaopresidente.pdf>

19. Texto disponível em: <www.fonaper.com.br/>

20. Página da Campanha disponível em: <www.brasilparatodos.org $>$. A petição encontra-se aberta na página <www.petitiononline.com/BrasVat/>

\section{Referências}

CUNHA, L.A.; CAVALIERE, A.M. O ensino religioso nas escolas públicas brasileiras: formação de modelos hegemônicos. In: PAIXÃO, L.; ZAGO, N. (Org.). Sociologia da educação - pesquisa e realidade brasileira. Petrópolis, Vozes, 2007.

CURY, C.R.J. Ensino religioso na escola pública: o retorno de uma polêmica recorrente. Revista Brasileira de Educação, São Paulo, n. 27, set./dez. 2004.

FISCHMANN, R. Estado laico. São Paulo: Memorial da América Latina, 2008.

OLIVEIRA, R.P. O ensino da religião nas escolas públicas: notas para um debate. In: Alves, A.; SouZA Junior, L. (Org.). Politicas públicas e práticas educativas. João Pessoa: Editora Universitária da UFPB, 2005. 